\title{
Thrombin Receptor Activation Elicits Rapid Protein Tyrosine Phosphorylation and Stimulation of the Raf-1/MAP Kinase Pathway Preceding Delayed Mitogenesis in Cultured Rat Aortic Smooth Muscle Cells
}

\section{Evidence for an Obligate Autocrine Mechanism Promoting Cell Proliferation Induced by G Protein-coupled Receptor Agonists}

\author{
Christopher J. Molloy, ${ }^{\star}$ John E. Pawlowski, ${ }^{*}$ David S. Taylor, ${ }^{\star}$ Christopher E. Turner, ${ }^{\ddagger}$ Helen Weber, ${ }^{*}$ Marianne Peluso, ${ }^{\star}$ \\ and Steven M. Seiler* \\ *Department of Cardiovascular Biochemistry, Bristol-Myers Squibb Pharmaceutical Research Institute, Princeton, New Jersey 08543; and \\ ${ }^{\ddagger}$ Department of Anatomy and Cell Biology, State University of New York-Health Science Center, Syracuse, New York 13210
}

\begin{abstract}
Treatment of quiescent rat aortic smooth muscle cells with either $\alpha$-thrombin or a thrombin receptor-derived agonist peptide (SFLLRNP) resulted in pronounced increases in $\left[{ }^{3} \mathrm{H}\right]$ thymidine incorporation that were concentration dependent and reached a maximum of $\sim 15$-fold above serum-starved controls. However, in contrast to FBS, PDGF$\mathrm{BB}$, or basic fibroblast growth factor (bFGF), that initiated DNA synthesis promptly after 16-19 h, thymidine incorporation in response to thrombin was delayed by an additional 3-6 h. Delayed mitogenesis correlated with the appearance of a potent mitogenic activity in conditioned media samples obtained from thrombin-stimulated rat aortic smooth muscle cells, as assayed using Swiss 3T3 fibroblasts. This activity was not inhibited by neutralizing antibodies directed against PDGF or bFGF. Furthermore, in the Swiss 3T3 cells, simple addition of either $\alpha$-thrombin or SFLLRNP failed to elicit a significant mitogenic response. In signal transduction studies, both thrombin and SFLLRNP treatment led to rapid tyrosine phosphorylation of proteins with apparent molecular masses of 42, 44, 75, 120, and $190 \mathrm{kD}$, respectively, as assessed by antiphosphotyrosine immunoblotting. The overall pattern of protein tyrosine phosphorylation was distinct from that observed after PDGF-BB addition. Activation of Raf-1 and the mitogen-activated protein (MAP) kinases $\mathrm{p} 44^{\text {mapk }}$ and $\mathrm{p} 42^{\text {mapk }}$ was also observed. However, the time course and duration of Raf-1/MAP kinase activation after thrombin stimulation were similar to those elicited by PDGF-BB. Taken together, our results indicate that thrombin-stimulated vascular smooth muscle proliferation is delayed and requires the de novo expression of one or more autocrine mitogens. In addition, the rapid induction of discrete intracellular signaling mechanisms by thrombin, including the Raf-1/MAP kinase pathway, appears to be in-
\end{abstract}

Address correspondence to Christopher J. Molloy, Ph.D., Dept. CV Biochemistry, K13-09, Bristol-Myers Squibb PRI, P.O. Box 4000, Princeton, NJ 08543. Phone: 609-252-4292; FAX: 609-252-6964; E-mail: Molloy@bms.com

Received for publication 10 July 1995 and accepted in revised form 14 December 1995.

J. Clin. Invest.

(C) The American Society for Clinical Investigation, Inc.

0021-9738/96/03/1173/11 \$2.00

Volume 97, Number 5, March 1996, 1173-1183 sufficient alone to promote vascular smooth muscle cell mitogenesis. (J. Clin. Invest. 1996. 97:1173-1183.) Key words: atherosclerosis • restenosis - smooth muscle • plateletderived growth factor $\bullet$ basic fibroblast growth factor

\section{Introduction}

The serine protease thrombin catalyzes fibrin clot formation and is a potent stimulator of blood platelets, vascular smooth muscle, and vascular endothelium. In blood vessels that have had their endothelium removed and in some vessels (e.g., rabbit aorta) with intact endothelium, catalytically active thrombin causes smooth muscle contraction (for review see reference 1). Since localized platelet deposition and organized thrombus formation accompany proliferative vascular lesions, thrombin has been implicated to play a role in atherogenesis and restenosis after balloon angioplasty (2-4). However, the exact role of thrombin on vascular cell growth and chronic vascular remodeling in vivo remains unclear.

In cultured rat aortic smooth muscle $(\mathrm{RASM})^{1}$ cells, thrombin has been reported to activate $\mathrm{Na}^{+} / \mathrm{H}^{+}$exchange and calcium mobilization (5). An increase in intracellular calcium was required for thrombin-induced expression of c-fos mRNA, a protooncogene associated with cell growth. However, thrombin stimulation of RASM cell DNA synthesis was not observed by these investigators, in spite of an increase in cell size, which was indicated by enhanced protein synthesis. These studies conflict with others that have demonstrated that thrombin is mitogenic in neonatal rat vascular smooth muscle (6), as well as various fibroblast cell lines $(7,8)$. More recently, thrombin has been shown to stimulate mitogenesis in cultured vascular smooth muscle cells (9). Furthermore, the mitogenic effects of thrombin could be mimicked by thrombin receptorderived peptides that activate the thrombin receptor (9). These results have implicated thrombin as a potential mediator of vascular smooth muscle cell proliferation in the vessel wall.

The cellular actions of thrombin are mediated by a novel membrane-spanning receptor (10; for a recent review see ref-

1. Abbreviations used in this paper: anti-P-TYR, antiphosphotyrosine antibodies; FAK, focal adhesion kinase; G protein, GTP-binding protein; GAP, GTPase-activating protein; MAP kinase, mitogen-activated protein kinase; MBP, myelin basic protein; PI-3-kinase, phosphoinositide-3-kinase; PLC, phospholipase C; RASM, rat aortic smooth muscle; SFLLRNP, 7-amino acid receptor-derived peptide agonist for the thrombin receptor. 
erence 11). Thrombin receptors have been identified on platelets $(10)$, endothelial cells $(10,12)$, fibroblasts $(13,14)$, vascular smooth muscle cells $(9,15)$, and other cell types. The thrombin receptor contains seven hydrophobic (membrane-spanning) domains and belongs to the family of $G$ protein-coupled receptors (10). $\alpha$-Thrombin binds to this receptor via an anionbinding exosite domain that interacts with the receptor sequence $\mathrm{TR}_{52-60}(10,16)$. Bound thrombin then cleaves a peptide bond on the carboxyl side of $\mathrm{Arg}_{41}$ exposing a new amino terminus $\left(\mathrm{NH}_{2}\right.$ terminus) on the receptor. This new $\mathrm{NH}_{2}$ terminus acts as a "tethered ligand" activating the receptor. Peptides containing the $\mathrm{NH}_{2}$-terminal receptor sequence SFLLR or SFFLR (of the human or rodent receptor, respectively), can activate the thrombin receptor without prior receptor cleavage. Accordingly, the involvement of the thrombin receptor in many of thrombin's actions on cells has been implicated using SFLLR-containing peptides.

Some of the thrombin-stimulated signaling mechanisms activated in cells expressing high-affinity receptors have been characterized (for review see reference 17). For example, in several cell types, thrombin stimulates phosphatidylinositolspecific phospholipase $\mathrm{C}$ activity through the activation of at least one closely coupled $\mathrm{G}$ protein (18-20). This results in the generation of the second messengers inositol trisphosphate and diacylglycerol, which are involved in intracellular $\mathrm{Ca}^{2+}$ mobilization and protein kinase $\mathrm{C}$ activation, respectively. Similarly, in common with many other growth factors, thrombin has been shown to activate cellular protein kinases that have been linked to mitogenesis. For example, thrombin stimulation of platelets $(21,22)$ and vascular smooth muscle cells (23) leads to rapid protein tyrosine phosphorylation of several proteins. However, the relevance of these early signaling events to the biological effects of thrombin is unclear, although recent studies implicate protein tyrosine kinase activity as a critical event in thrombin-stimulated growth (23).

In this report, we have characterized both the biological and biochemical consequences of thrombin receptor activation in cultures of RASM cells that display a neointimal phenotype. These studies confirm that thrombin receptor activation leads to productive mitogenic signaling, although stimulation of DNA synthesis is significantly delayed in comparison to mitogens such as FBS, PDGF-BB, or basic fibroblast growth factor (bFGF). Delayed mitogenesis correlates with the appearance of a mitogenic activity in RASM cell conditioned medium, thus representing a possible autocrine mediator of cell proliferation that is upregulated by thrombin receptor activation. Of interest, some early downstream signal transduction events stimulated by thrombin and agonist peptide are similar to those activated by polypeptide growth factors, including rapid protein tyrosine phosphorylation of a subset of intracellular proteins and concomitant activation of ancillary protein kinases. Taken together, these data indicate that early signaling events stimulated after thrombin receptor activation may be only indirectly involved in the induction of DNA synthesis, via stimulation of a productive autocrine loop involving one or more endogenously produced mitogens.

\section{Methods}

Cell culture. Primary RASM cells were generously provided by Dr. Marschall Runge (Emory University, Atlanta, GA). These cells stain positively for smooth muscle $\alpha$-actin, express angiotensin type I
$\left(\mathrm{AT}_{1}\right)$ receptors, and secrete osteopontin, a phosphorylated glycoprotein marker for the neointimal vascular smooth muscle phenotype (24). All cells were routinely analyzed for mycoplasma contamination before use. Cells were grown in DME (with D-glucose [4,500 mg/liter], L-glutamine, and Hepes buffer [ $25 \mathrm{mM}])$ containing FBS $(10 \%$ $\mathrm{vol} / \mathrm{vol})$ and penicillin $(100 \mathrm{U} / \mathrm{ml})$-streptomycin $(100 \mathrm{mg} / \mathrm{ml})$. Cells were passaged at $80-90 \%$ confluence with $0.25 \%$ trypsin and were used between passages 10 and 18. Swiss 3T3 mouse fibroblasts were obtained from American Type Culture Collection (Rockville, MD). Fibroblasts were maintained in DME plus $10 \%$ calf serum and antibiotics. All culture reagents were obtained from GIBCO-BRL (Grand Island, NY) unless otherwise specified.

Growth factors, antibodies, and other reagents. Recombinant human PDGF-AA and -BB homodimers were purchased from R\&D Systems (Minneapolis, MN). Polyclonal goat anti-PDGF (A- and B-chain) and polyclonal sheep anti-bFGF neutralizing antibodies were from Collaborative Research Inc. (Bedford, MA). Recombinant human bFGF was from Genzyme Corp. (Boston, MA). Polyclonal rabbit anti-PDGF-AA and monoclonal anti-bFGF (bovine) neutralizing antibodies, anti-mitogen-activated protein (MAP) kinase (R2) and anti-phosphatidylinositol-3-kinase (PI-3-kinase) antisera, as well as murine monoclonal antibodies directed against phospholipase $\mathrm{C}-\gamma$ (PLC- $\gamma$ ) and phosphotyrosine (anti-P-TYR), were purchased from Upstate Biotechnology, Inc. (Lake Placid, NY). Antipeptide antiserum to the $\mathrm{p} 21^{\text {ras }}$ GTPase-activating protein (GAP) was prepared as previously described (25). Polyclonal anti-Raf-1 peptide antiserum was generously provided by Dr. Keith Robbins (National Institutes of Health, Rockville, MD). Mouse monoclonal anti-MAP kinase antibodies were purchased from Zymed Laboratories, Inc. (South San Francisco, CA). Human $\alpha$-thrombin $(3,080 \mathrm{U} / \mathrm{mg}, 4,096 \mathrm{U} / \mathrm{ml})$ was obtained from Enzyme Research Laboratories (South Bend, IN). The thrombin receptor activating peptide, SFLLRNP-amide (SFLLRNP), was synthesized by automated solid phase synthesis on a Milligen/ Biosearch 9600 using standard t-Boc protocols (26) or was purchased from BACHEM Bioscience Inc. (Philadelphia, PA). Hirudin was purchased from Calbiochem-Novabiochem Corp. (San Diego, CA). Prestained molecular weight standards for polyacrylamide gels were obtained from Amersham Corp. (Arlington Heights, IL).

Conditioned media collection. To obtain samples of conditioned media, confluent cultures of RASM cells were first growth-arrested by incubation for $48 \mathrm{~h}$ in a chemically defined serum-free medium (SF-DME) (DME supplemented with $10 \mathrm{nM}$ selenium [GIBCO/ BRL] and $10 \mu \mathrm{g}$ of transferrin/ml [Collaborative Research Inc.]). The cells were then either left untreated or stimulated with thrombin (10 $\mathrm{nM})$ or SFLLRNP $(100 \mu \mathrm{M})$ for the indicated times. Samples of conditioned media from the RASM cells were collected, and aliquots were either used immediately or were frozen on dry ice and stored at $-80^{\circ} \mathrm{C}$.

Mitogenic assays. RASM cells were plated in serum-containing medium on fibronectin-coated 24-well tissue culture plates. After attachment, cells were rinsed twice with PBS and incubated for $72 \mathrm{~h}$ in SF-DME. Quiescent cells were labeled with $\left[{ }^{3} \mathrm{H}\right]$ thymidine $(1 \mu \mathrm{Ci} / \mathrm{ml}$, 70-90 Ci/mmol) (DuPont/NEN Research Products, Boston, MA) in the absence or presence of FBS $(10 \% \mathrm{vol} / \mathrm{vol})$ or test mitogens for 24-48 h. In some experiments, insulin $(10 \mu \mathrm{g} / \mathrm{ml})$ was also added to SF-DME, and cells were pulse-labeled with $\left[{ }^{3} \mathrm{H}\right]$ thymidine for the final $3 \mathrm{~h}$ of the time course. In instances that required thrombin inactivation, hirudin $(4 \mathrm{U} / \mathrm{ml})$ was also included $30 \mathrm{~min}$ before the addition of test mitogens and coincubated throughout the experiment. Relative $\left[{ }^{3} \mathrm{H}\right]$ thymidine incorporation was determined by liquid scintillation spectrometry after precipitation with ice-cold trichloroacetic acid $(5 \% \mathrm{wt} / \mathrm{vol})$ and solubilization $\left(37^{\circ} \mathrm{C}\right)$ in $\mathrm{NaOH}(0.25 \mathrm{M})$.

For assays of RASM cell-derived conditioned medium samples, Swiss 3 T3 cells were plated as described then serum-starved for $18 \mathrm{~h}$ in SF-DME supplemented with $0.1 \%$ bovine serum albumin. Control growth factors or conditioned media were incubated $\left(37^{\circ} \mathrm{C}, 30 \mathrm{~min}\right)$ in the absence or presence of growth factor neutralizing antibodies before addition to the cells. The cells were incubated for $16 \mathrm{~h}$ followed 
by pulse-labeling with $\left[{ }^{3} \mathrm{H}\right]$ thymidine for an additional $6 \mathrm{~h}$. Relative $\left[{ }^{3} \mathrm{H}\right]$ thymidine incorporation was determined as described above.

Cell proliferation assays. RASM cells $\left(5 \times 10^{4}\right.$ cells $\left./ \mathrm{ml}\right)$ were plated in 96-well microtiter plates and grown in serum-containing media. After $24 \mathrm{~h}$, growth medium was removed and replaced with SFDME for $24 \mathrm{~h}$. Cells were then treated with increasing concentrations of thrombin in SF-DME supplemented with $0.5 \%$ FBS to promote cytokinesis. In some experiments, hirudin was also included $(10 \mathrm{U} / \mathrm{ml})$. After $48 \mathrm{~h}$, viable cell number was determined using the CellTiter $96^{\mathrm{TM}}$ AQueous Non-Radioactive Cell Proliferation Assay kit (Promega Inc., Madison, WI). In this assay, dehydrogenase enzymes in metabolically active cells reduce the combination of [3-(4,5-dimethylthiazol-2-yl)-5(3-carboxymethoxyphenyl)-2-(4-sulfophenyl)- ${ }^{2} \mathrm{H}$-tetrazolium, MTS] and an electron coupling reagent (phenazine methosulfate) to produce formazan, detectable at $490 \mathrm{~nm}$ using a microtiter plate reader $\left(\mathrm{UV}_{\max }\right.$; Molecular Devices, Menlo Park, CA). Product formation is directly proportional to viable cell number.

Immunoprecipitation and immunoblot analyses. Confluent cultures of cells were incubated for $48 \mathrm{~h}$ in SF-DME to induce quiescence. The cells were then either left untreated or stimulated with agonists for the indicated times. In experiments in which hirudin was used as a thrombin antagonist, the compound was added to cells 30 min before agonist addition. Cultures were rinsed twice in ice-cold PBS containing $1 \mathrm{mM} \mathrm{Na}_{3} \mathrm{VO}_{4}$, and then lysed on ice in $0.5 \mathrm{ml}$ of P-TYR lysis buffer (50 mM Hepes, $\mathrm{pH} 7.5,1 \%$ Triton X-100, $50 \mathrm{mM}$ $\mathrm{NaCl}, 50 \mathrm{mM} \mathrm{NaF}, 10 \mathrm{mM}$ sodium pyrophosphate, $5 \mathrm{mM}$ EDTA, $1 \mathrm{mM} \mathrm{Na}_{3} \mathrm{VO}_{4}, 1 \mathrm{mM}$ PMSF, plus $10 \mu \mathrm{g} / \mathrm{ml}$ of aprotinin and leupeptin). Lysates were sonicated for $10 \mathrm{~s}$ and then centrifuged at $14,000 \mathrm{~g}$ for $10 \mathrm{~min}$ at $4^{\circ} \mathrm{C}$. Equal protein aliquots (typically, 1-2 mg protein) were used for immunoprecipitations. For antiphosphotyrosine analysis, $2 \mu \mathrm{g}$ of anti-P-TYR was used per milligram of cell lysate. For immunoprecipitation of MAP kinases, cell lysates were first boiled for $5 \mathrm{~min}$ in the presence of $1 \%$ SDS, and then diluted with nine parts P-TYR lysis buffer before addition of anti-MAP kinase antibodies $(10 \mu \mathrm{g})$. All immunoprecipitations were carried out for $2 \mathrm{~h}$ at $4^{\circ} \mathrm{C}$, and immune complexes were recovered using protein $\mathrm{G}$-agarose (GammaBind G; Pharmacia Biotech Inc., Piscataway, NJ). Immunoprecipitates were washed five times in P-TYR lysis buffer, solubilized in SDS-PAGE sample buffer, and resolved by SDS-polyacrylamide electrophoresis and immunoblotting as described $(27,28)$. Aliquots of the whole cell lysates $(100 \mu \mathrm{g})$ removed before immunoprecipitation were routinely analyzed by immunoblotting. Immunoreactive bands were visualized using [ $\left.{ }^{125} \mathrm{I}\right]$-protein A (Amersham Inc.), followed by autoradiography.

MAP kinase activation assays. Immune complex kinase reactions were performed as previously described with minor modifications (29). Briefly, confluent cultures of RASM cells were serum deprived for $48 \mathrm{~h}$ in SF-DME. The cells were stimulated with either $\alpha$-thrombin $(10 \mathrm{nM})$ or PDGF-BB $(50 \mathrm{ng} / \mathrm{ml})$ for the indicated times at $37^{\circ} \mathrm{C}$. Cell lysates were prepared in P-TYR lysis buffer as described above and $444^{m a p k}$ was immunoprecipitated using $5 \mu \mathrm{g}$ of anti-rat MAP kinase (R2) antiserum per $400 \mu \mathrm{g}$ of cell lysate. The immunoprecipitations were carried out for $2 \mathrm{~h}$ at $4^{\circ} \mathrm{C}$, and immune complexes were recovered using GammaBind G. The immunoprecipitates were washed four times with P-TYR lysis buffer and once with kinase buffer (20 $\mathrm{mM}$ Hepes, $\mathrm{pH} 7.4,10 \mathrm{mM} \mathrm{MgCl} 2,1 \mathrm{mM}$ DTT, and $10 \mathrm{mM} p$-nitrophenylphosphate). $\mathrm{p} 44^{\text {mapk }}$ activity was determined by measuring the incorporation of $\left[{ }^{32} \mathrm{P}\right]$ into myelin basic protein (MBP). The immunoprecipitates were resuspended in $50 \mu \mathrm{l}$ of kinase buffer, and the reactions were initiated by the addition of $5 \mu \mathrm{g}$ of MBP and ATP $(20 \mathrm{mM}$ final, $5 \mu \mathrm{Ci}\left[\gamma^{-32} \mathrm{P}\right] \mathrm{ATP}$ per reaction). The kinase reactions were carried out for $10 \mathrm{~min}$ at $30^{\circ} \mathrm{C}$, quenched by the addition of $12 \mu \mathrm{l}$ of $5 \times$ SDS-PAGE sample buffer, and heated for $5 \mathrm{~min}$ at $95^{\circ} \mathrm{C}$. The samples were resolved by $12.5 \%$ SDS-PAGE, and the proteins were electrophoretically transferred to PVDF membranes (Immobilon P; Millipore Corp., Bedford, MA). Incorporation of $\left[{ }^{32} \mathrm{P}\right]$ into MBP was determined by PhosphorImager analysis (Molecular Dynamics, Inc., Sunnyvale, CA).

\section{Results}

In cultured RASM cells, $\alpha$-thrombin and SFLLRNP are weakly mitogenic after $24 \mathrm{~h}$, but stimulate a pronounced increase in $D N A$ synthesis evident after $48 \mathrm{~h}$. To evaluate the effects of thrombin on vascular smooth muscle cell proliferation, mitogenic assays were performed using cultured primary RASM cells. In control experiments, cells were incubated without (serum-free, SF) or with the potent mitogenic factors FBS, PDGF-BB, or bFGF. In parallel dishes, cells were treated with $\alpha$-thrombin, $\alpha$-thrombin plus hirudin, SFLLRNP, and an inactive acetylated SFLLRNP control (ac-SFLLRNP). When DNA synthesis was measured after $24 \mathrm{~h}, \alpha$-thrombin and SFLLRNP stimulated only minor (two- to threefold) increases in $\left[{ }^{3} \mathrm{H}\right]$ thymidine incorporation (Fig. 1). In contrast, FBS, PDGF-BB, and bFGF induced 15-, 19-, and 15-fold increases over the serum-free control, respectively.

Mitogenic assays were then extended to $48 \mathrm{~h}$ to determine if mitogenic effects induced by thrombin might be delayed in comparison to those produced by FBS, PDGF-BB, or bFGF. Under these conditions, the relative levels of DNA synthesis stimulated by FBS, PDGF-BB, and bFGF were 14-, 11-, and 10 -fold above the serum-starved controls, respectively. However, in contrast to results observed at $24 \mathrm{~h}$, after $48 \mathrm{~h}$ thrombin and SFLLRNP each stimulated 10- and 8-fold increases in DNA synthesis in comparison to quiescent controls (Fig. 1, solid bars). Furthermore, thrombin-stimulated DNA synthesis was inhibited by hirudin, a specific thrombin antagonist. The acetylated SFLLRNP control peptide failed to stimulate DNA synthesis.

To further investigate the mechanisms involved in thrombinstimulated growth, we determined the time course of $\left[{ }^{3} \mathrm{H}\right]$ thy-

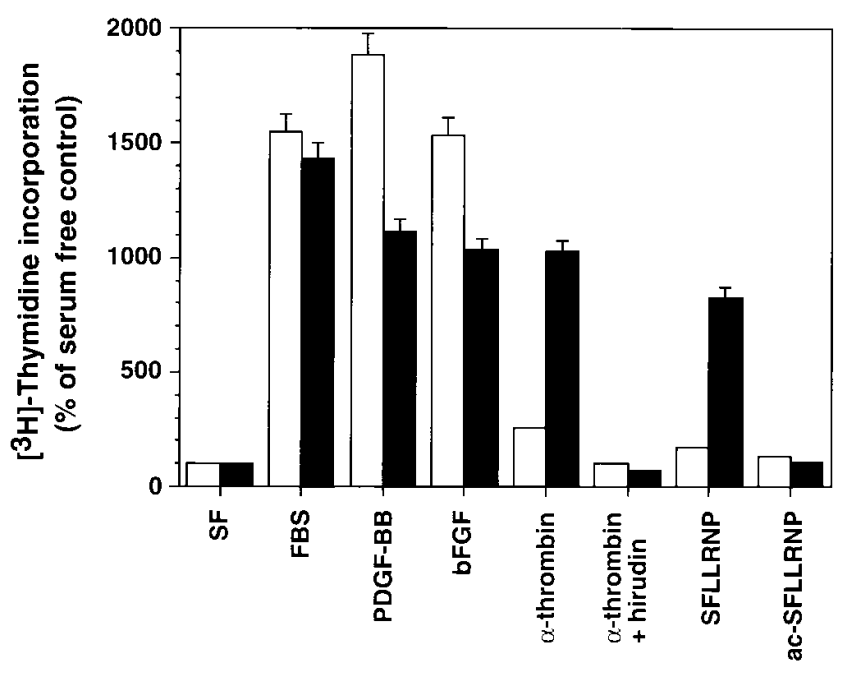

Figure 1. Delayed mitogenic effects of $\alpha$-thrombin and SFLLRNP on RASM cells. Cells were incubated for $24 \mathrm{~h}$ (open bars) or $48 \mathrm{~h}$ (solid bars) with $\left[{ }^{3} \mathrm{H}\right]$ thymidine in SF-DME plus the indicated treatments. Treatments included: FBS (10\% vol/vol), PDGF-BB $(20 \mathrm{ng} / \mathrm{ml})$, bFGF (20 ng/ml), $\alpha$-thrombin (10 nM), $\alpha$-thrombin plus hirudin (10 $\mathrm{U} / \mathrm{ml})$, SFLLRNP $(200 \mu \mathrm{M})$, and an inactive acetylated SFLLRNP control $(200 \mu \mathrm{M})$. Results are expressed as a percentage of the unstimulated serum free $(S F)$ controls. Baseline $\left[{ }^{3} \mathrm{H}\right]$ thymidine incorporation was $7,450 \pm 1,400 \mathrm{cpm}$ at $24 \mathrm{~h} ; 13,380 \pm 4,550 \mathrm{cpm}$ at $48 \mathrm{~h}$. Bars represent the mean \pm SD of three treatment wells from a representative experiment. 
midine incorporation in the RASM cells by two methods. In the first series of experiments, serum-starved cells were stimulated with either FBS, PDGF-BB homodimer, or $\alpha$-thrombin and total $\left[{ }^{3} \mathrm{H}\right]$ thymidine incorporation was determined after various time intervals. As shown in Fig. $2 A$, FBS and PDGF$\mathrm{BB}$ each initiated RASM cell DNA synthesis between 16 and $19 \mathrm{~h}$, with peak incorporation at $\sim 28 \mathrm{~h}$. In contrast, thrombin stimulated more modest levels of DNA synthesis in the RASM cells which were delayed until $\sim 25 \mathrm{~h}$ after ligand addition, with a peak at $32-36 \mathrm{~h}$.

In a second series of experiments, the time course analysis was repeated using cells that were pulse-labeled with $\left[{ }^{3} \mathrm{H}\right]$ thymidine for $3 \mathrm{~h}$ before extraction. In these experiments, insulin was also included as cofactor $(30,31)$. As shown in Fig. $2 B$, the insulin addition alone had no effect on $\left[{ }^{3} \mathrm{H}\right]$ thymidine incorporation in the controls. After addition of PDGF-BB, DNA synthesis was observed to begin before the $16 \mathrm{~h}$ time point with a peak of incorporation at $25 \mathrm{~h}$. Under these conditions, thrombin-stimulated $\left[{ }^{3} \mathrm{H}\right]$ thymidine incorporation was not observed until $22 \mathrm{~h}$ (a delay of at least $3 \mathrm{~h}$ compared with PDGF-BB), with peak incorporation occurring at $28 \mathrm{~h}$. Taken together, these data confirm that the mitogenic response of RASM cells to thrombin is delayed $3-6 \mathrm{~h}$ in comparison to PDGF-BB or FBS.

Thrombin and SFLLRNP stimulate concentration-dependent increases in DNA synthesis and cell proliferation in cultured RASM cells. Additional experiments were performed to determine if stimulation of delayed DNA synthesis by thrombin and SFLLRNP was concentration dependent. In these studies, quiescent RASM cells were exposed to increasing concentrations of either $\alpha$-thrombin or SFLLRNP, and relative levels of DNA synthesis were determined after $48 \mathrm{~h}$. For $\alpha$-thrombin, maximal DNA synthesis (15-fold above control) was observed at a concentration of $\sim 1 \mathrm{nM}$ (Fig. $3 A$ ). This response was half-maximal at a concentration of $\sim 0.3 \mathrm{nM}$. SFLLRNP was less potent than $\alpha$-thrombin as a mitogen. Maximal SFLLRNP-stimulated DNA synthesis was observed at $300 \mu \mathrm{M}$.

In addition to mitogenic assays, the effects of thrombin on RASM cell proliferation were examined. Thrombin stimulated a concentration-dependent increase in RASM cell number after treatment for $48 \mathrm{~h}$ (Fig. $3 \mathrm{~B}$ ). Maximal increases in cell proliferation were observed at a thrombin concentration of 10 $\mathrm{nM}$. Thrombin-stimulated proliferation was blocked by inclusion of hirudin $(10 \mathrm{U} / \mathrm{ml})$. Hirudin had no effect on serum- or PDGF-stimulated cell proliferation (data not shown).

Thrombin stimulates the secretion of a mitogenic activity from RASM cells and acts as a comitogenic factor: detection by Swiss 373 fibroblast mitogenic assays. To determine whether thrombin receptor activation induced the secretion of mitogenic factor(s) from RASM cells, matched conditioned medium samples from serum-starved RASM cells (control) and cells stimulated by thrombin or SFLLRNP for various times were added to quiescent cultures of Swiss $3 \mathrm{~T} 3$ cells, and $\left[{ }^{3} \mathrm{H}\right]$ thymidine incorporation was measured after $22 \mathrm{~h}$. As controls, some of the cells were stimulated directly with either thrombin or SFLLRNP. As shown in Fig. $4 A$, purified thrombin or SFLLRNP failed to stimulate significant DNA synthesis in the Swiss $3 T 3$ cells, despite the fact that these cells express thrombin receptors (Seiler, S.M., unpublished observations) (32). In contrast, conditioned media samples obtained from RASM cells stimulated with either thrombin or SFLLRNP
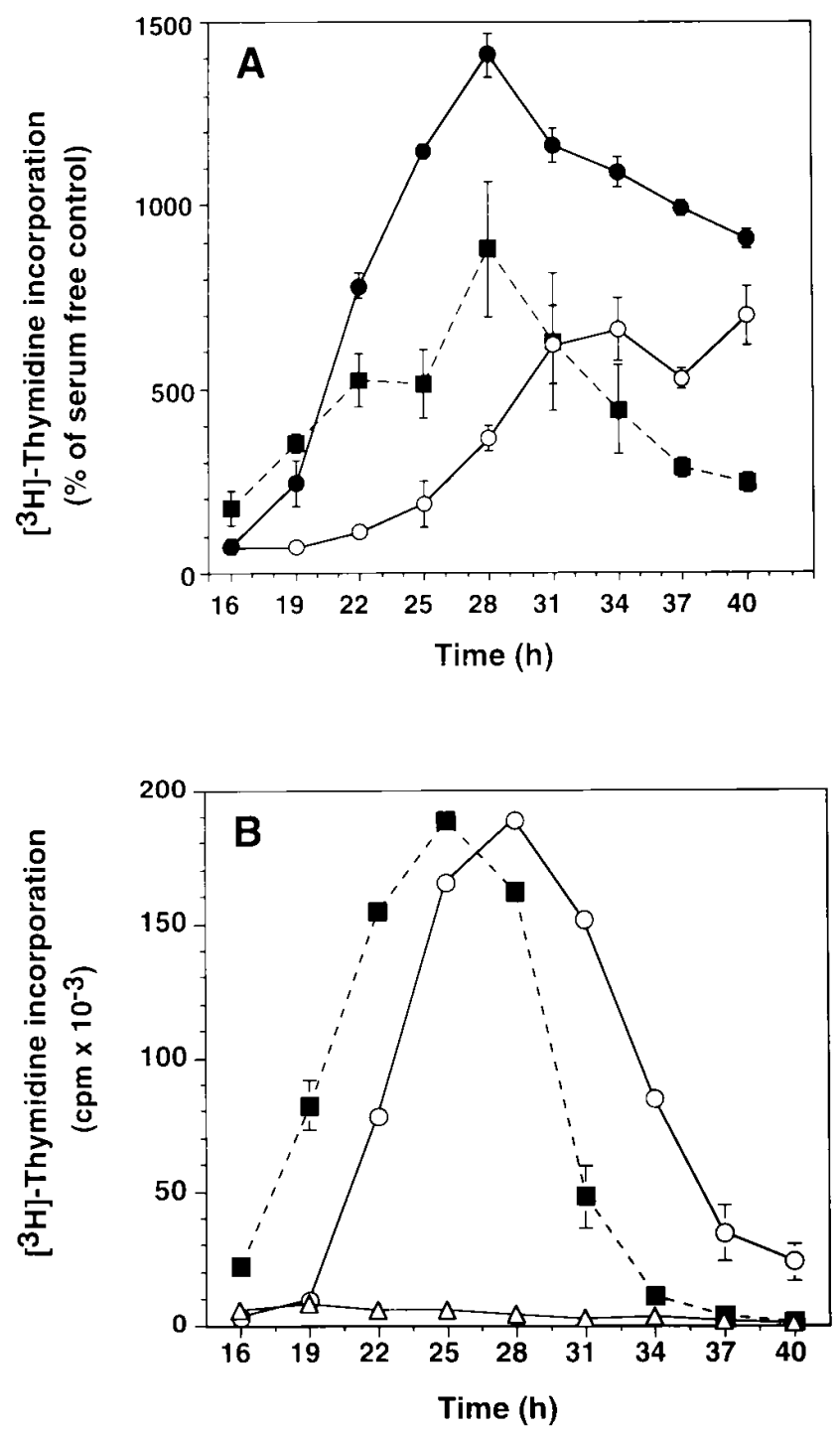

Figure 2. Time course of $\left[{ }^{3} \mathrm{H}\right]$ thymidine incorporation in thrombinstimulated RASM cells. $(A)$ Quiescent RASM cells $\left(5 \times 10^{4}\right.$ cells/ well) were stimulated for the indicated times with FBS $(10 \%$, closed circles), PDGF-BB (20 ng/ml, closed squares), or $\alpha$-thrombin $(10 \mathrm{nM}$, open circles) in the presence of $\left[{ }^{3} \mathrm{H}\right]$ thymidine. Relative $\left[{ }^{3} \mathrm{H}\right]$ thymidine incorporation was determined by liquid scintillation spectrometry. Results are expressed as a percentage of the serum-free control levels; points are the mean \pm SD of three treatment wells from a representative experiment. $(B)$ Serum-starved RASM cells were treated for the indicated times with SF-DME supplemented with insulin (10 $\mu \mathrm{g} / \mathrm{ml}$, open triangles), insulin plus PDGF-BB (20 ng/ml, closed squares), or insulin plus $\alpha$-thrombin $(10 \mathrm{nM}$, open circles $)$. Cells were labeled with $\left[{ }^{3} \mathrm{H}\right]$ thymidine for the final $3 \mathrm{~h}$. Results are expressed as mean $\left[{ }^{3} \mathrm{H}\right]$ thymidine incorporation $\left(\mathrm{cpm} \times 10^{-3}\right) \pm \mathrm{SD}$ of three treatment wells.

(6-24 h) demonstrated increased mitogenic activity compared with conditioned media samples from unstimulated cells. This finding supports the hypothesis that thrombin receptor agonists stimulate the release of autocrine mitogens from the RASM cells.

In studies using cultured vascular smooth muscle cells, thrombin has been reported to be synergistic with specific mitogens, including bFGF (33), PDGF, and FBS (34). Therefore, 

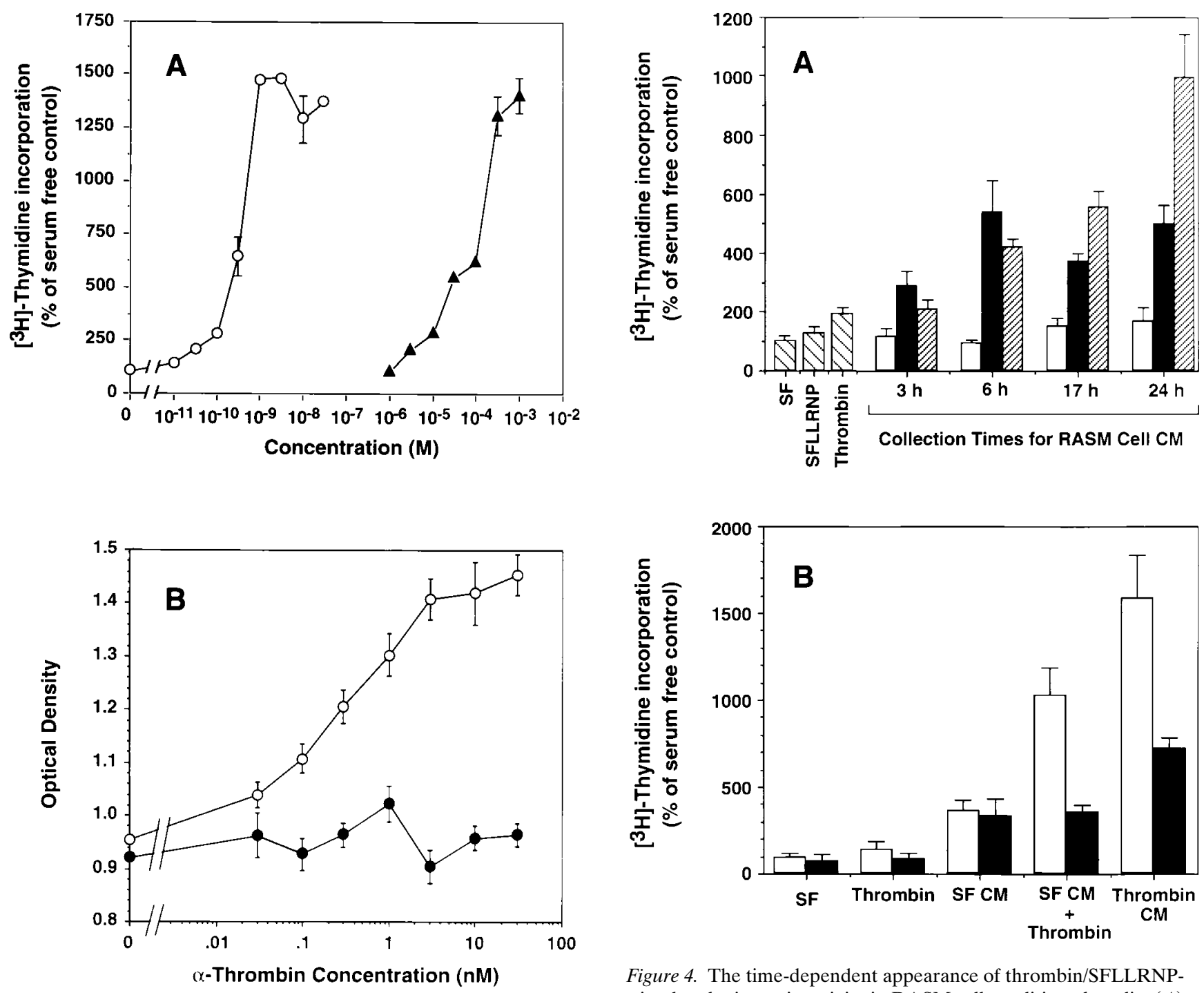

Figure 4. The time-dependent appearance of thrombin/SFLLRNPstimulated mitogenic activity in RASM cell conditioned media. (A) Swiss 3 T3 cells $\left(7 \times 10^{4}\right.$ cells/well $)$ were incubated for $22 \mathrm{~h}$ with either serum-free medium $(S F)$, SFLLRNP $(100 \mu \mathrm{M}), \alpha$-thrombin $(10 \mathrm{nM})$, or conditioned media $(C M)$ samples as indicated. CM samples were collected at the indicated times from unstimulated RASM cells (control, open bars) or cells treated with either SFLLRNP $(100 \mu \mathrm{M}$, solid bars) or $\alpha$-thrombin ( $10 \mathrm{nM}$, hatched bars). Mitogenic activity was measured as $\left[{ }^{3} \mathrm{H}\right]$ thymidine incorporation as described in Methods and represents the mean $\pm \mathrm{SD}$ of three measurements from a representative experiment. Baseline $\left[{ }^{3} \mathrm{H}\right]$ thymidine incorporation of the SF sample was 5,700 $\pm 760 \mathrm{cpm}$. (B) Mitogenic activity was measured in Swiss $3 \mathrm{~T} 3$ cells treated with either serum-free medium $(S F)$, thrombin $(10 \mathrm{nM})$, or samples of control conditioned media from RASM cells incubated for $24 \mathrm{~h}$ in serum-free conditions $(S F C M)$, in the presence of thrombin $(10 \mathrm{nM}$, Thrombin CM), or SF CM plus freshly added thrombin $(10 \mathrm{nM})$. In some of the samples, recombinant hirudin ( $4 \mathrm{U} / \mathrm{ml}$ ) was added before addition to the cells (solid bars). The data are expressed as the mean \pm SD of three measurements from a representative experiment. Baseline $\left[{ }^{3} \mathrm{H}\right]$ thymidine incorporation of the SF sample was $3,040 \pm 590 \mathrm{cpm}$.

thrombin-stimulated cells also contained thrombin, we investigated whether thrombin augmented mitogenic activity in these samples. The comitogenic effects of thrombin were evaluated using Swiss 3 T3 cells (Fig. 4 B). In these experiments, the mitogenic activity of conditioned media samples from unstimulated, control RASM cells ( $S F C M, 24 \mathrm{~h}$ ) was determined in the absence or presence of added thrombin and compared with that produced by conditioned medium obtained from

thrombin-stimulated RASM cells (Thrombin CM, 24 h). In addition, in some of the assays, hirudin was added to the conditioned media samples before exposure to the cells. As shown in Fig. $4 B$, pure thrombin elicited only a minor, twofold increase in $\left[{ }^{3} \mathrm{H}\right]$ thymidine incorporation in the Swiss $3 \mathrm{~T} 3$ cells 
that was blocked by hirudin. In contrast, conditioned media samples from control and thrombin-stimulated RASM cells produced 4- and 15-fold increases in $\left[{ }^{3} \mathrm{H}\right]$ thymidine incorporation. Of interest, we found that the addition of thrombin to control conditioned media samples increased $\left[{ }^{3} \mathrm{H}\right]$ thymidine incorporation significantly, to $\sim 10$-fold in Swiss 3 T3 cells. Furthermore, this increased mitogenic activity was completely blocked by hirudin. These data imply that thrombin is a potent comitogen for RASM conditioned media factors, since its addition alone to the Swiss 3 T3 cells failed to stimulate DNA synthesis.

Fig. $4 \mathrm{~B}$ also shows that hirudin reduced the mitogenic effects of thrombin-stimulated RASM conditioned media samples, presumably by blocking comitogenic effects of residual thrombin. However, the hirudin-insensitive mitogenic activity of these samples remained at least twofold greater than that elicited by control conditioned media samples (Fig. $4 \mathrm{~B}$ ). Thus, these data imply that thrombin stimulates the secretion of mitogenic factor(s) from RASM cells. Whether thrombin stimulates an increase in basally expressed RASM cell mitogenic factors or induces the expression of new factors is currently being explored.

Neutralizing antibodies directed against PDGF or bFGF fail to inhibit the mitogenic activity present in conditioned media samples derived from thrombin-stimulated RASM cells. Autocrine production of the growth factors PDGF-AA $(34,35)$ and bFGF (33) has been proposed to contribute to thrombininduced mitogenesis in vascular smooth muscle cells. Therefore, PDGF and bFGF neutralizing antibodies were used to identify these factors as possible mitogenic components in conditioned media samples obtained from thrombin-stimulated RASM cells (Fig. 5). As shown in Fig. $5 A$, in control experiments, DNA synthesis stimulated by PDGF-AA, -BB, or bFGF in the Swiss 3 T3 cells was effectively inhibited by preincubation with the appropriate specific neutralizing antibodies. Furthermore, when a combination of PDGF-AA and bFGF was used as a mitogenic stimulus, only coaddition of neutralizing antibodies directed against both PDGF-AA and bFGF completely inhibited Swiss 3T3 DNA synthesis. In contrast, when samples of thrombin-stimulated RASM cell conditioned media were pretreated with growth factor neutralizing antibodies, either alone or in combination, we failed to observe any significant inhibition of mitogenic activity toward the Swiss 3 T3 cells (Fig. 5 B). Although it is theoretically possible that some of the growth factor neutralizing antibodies might not have efficiently recognized endogenous rat proteins, similar results were also obtained using several other commercially available PDGF and bFGF neutralizing antibody preparations $^{2}$ (see also reference 36 ). Taken together these results imply that neither PDGF nor bFGF contributes significantly to the mitogenic activity present in conditioned medium derived from thrombin-stimulated RASM cells.

Thrombin and agonist peptide stimulate rapid protein tyrosine phosphorylation in cultured RASM cells. To evaluate the effects of thrombin and SFLLRNP on protein tyrosine phosphorylation, confluent quiescent cultures of RASM cells were either left untreated (control) or were challenged with either $\alpha$-thrombin or SFLLRNP for different times. Cell lysates were then prepared and subjected to immunoblot analysis with

2. Molloy, C.J., unpublished observations.
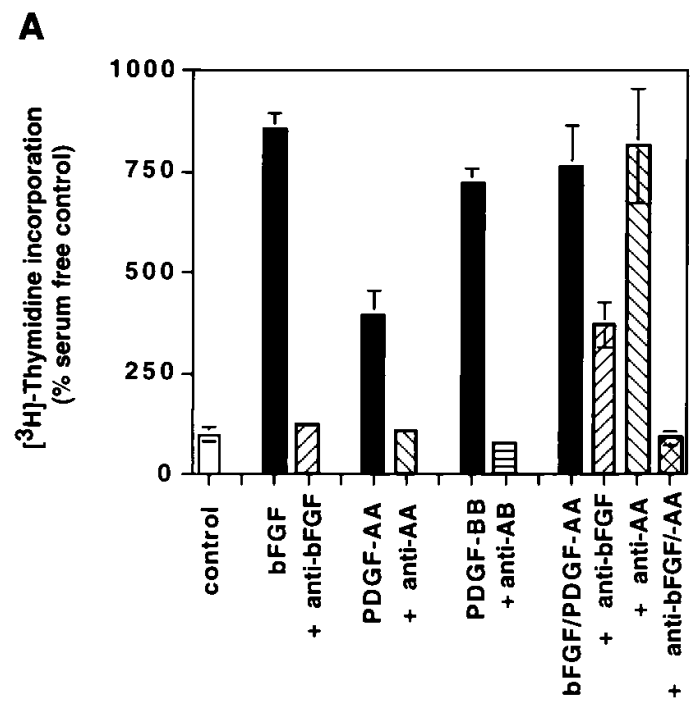

B

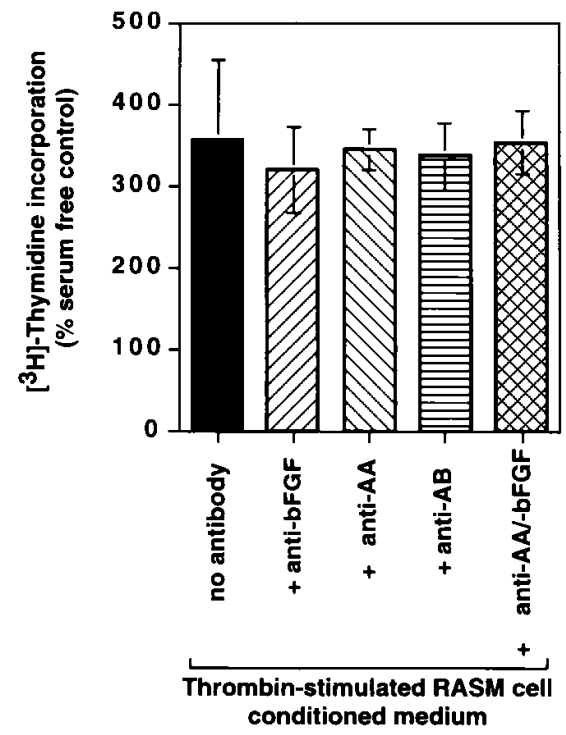

Figure 5. Effect of growth factor neutralizing antibodies on $\left[{ }^{3} \mathrm{H}\right]$ thymidine incorporation in Swiss 3 T3 cells stimulated with conditioned medium from thrombin-treated RASM cells. $(A)$ Serum-starved Swiss 3 T3 cells in 24-well tissue culture plates were treated with bFGF ( $5 \mathrm{ng} / \mathrm{ml})$, PDGF-AA ( $5 \mathrm{ng} / \mathrm{ml})$, PDGF-BB $(5 \mathrm{ng} / \mathrm{ml})$, or a combination of bFGF plus PDGF-AA for $24 \mathrm{~h}$. Where indicated, growth factor neutralizing antibodies (sheep polyclonal anti-bFGF, rabbit polyclonal anti-PDGF-AA, goat polyclonal anti-PDGF-AB; $25 \mu \mathrm{g} / \mathrm{ml}$ of each) were mixed with the growth factors for $30 \mathrm{~min}$ before addition to the cells. Cells were labeled with $\left[{ }^{3} \mathrm{H}\right]$ thymidine for the final $3 \mathrm{~h}$ as described in Methods. Relative levels of DNA synthesis were expressed as a percentage of serum-starved control group. Data points represent the mean $\pm \mathrm{SD}$ of three treatment wells from a representative experiment. (B) Quiescent Swiss 3T3 cells were treated with mitogenic conditioned medium obtained from RASM cells treated with $10 \mathrm{nM}$ thrombin for $24 \mathrm{~h}$. Where indicated, the conditioned medium samples were preincubated with specific growth factor neutralizing antibodies $(25 \mu \mathrm{g} / \mathrm{ml})$, alone or in combination, for $30 \mathrm{~min}$.

monoclonal antiphosphotyrosine antibodies. Both thrombin and SFLLRNP stimulated tyrosine phosphorylation of cellular proteins of apparent molecular masses of 42, 44, 75, 120, and $190 \mathrm{kD}$ (Fig. 6 A). Tyrosine phosphorylation of these bands was observed within $1 \mathrm{~min}$ and was maximal at $\sim 10 \mathrm{~min}$ after 
exposure of the cells to the respective agonists, with the exception of $\mathrm{p} 190$. Protein tyrosine phosphorylation of the 120- and $75-\mathrm{kD}$ proteins was sustained for $>90 \mathrm{~min}$ from the time of a single addition of each agonist. Tyrosine phosphorylation of p190 was decreased as early as 5 min after thrombin receptor activation, whereas phosphorylation of the 42- and 44-kD bands decreased substantially by $60 \mathrm{~min}$ (Fig. $6 \mathrm{~A}$ ). It should be noted that the pattern of protein tyrosine phosphorylation induced after thrombin receptor activation in the RASM cells was identical to that elicited by angiotensin II and endothelin-1 $(37,38)$, suggesting that these agonists may act by a common mechanism.

Characterization of thrombin-stimulated tyrosine phosphorylated proteins in RASM cells. Several protein substrates for activated growth factor receptor tyrosine kinases have been implicated in cellular mitogenesis (for recent reviews see references 39-41). These include molecules such as PLC- $\gamma$ (145 $\mathrm{kD})$, p21 ${ }^{\text {ras }}$ GAP (125 kD), and PI-3-kinase (85 kD). Using antibodies to these proteins, we analyzed anti-P-TYR immunoprecipitates from cells stimulated by $\alpha$-thrombin and compared these with anti-P-TYR recovered proteins after stimulation of cells with PDGF-BB. As shown in Fig. $5 B$, anti-P-TYR recovery of PLC- $\gamma$, PI-3-kinase, and GAP was observed after stimulation of RASM cells with PDGF-BB (Fig. 6 B, lane 2). However, we failed to detect significant tyrosine phosphorylation of these molecules in response to thrombin (Fig. $6 \mathrm{~B}$, lane $3)$. These data further indicate that thrombin stimulates a distinct pattern of protein tyrosine phosphorylation from that of the receptor tyrosine kinases in RASM cells.

The 42- and 44-kD tyrosine phosphorylated proteins observed in response to thrombin receptor activation correspond to MAP kinases. Recent studies have demonstrated that $\mathrm{p} 44^{\text {mapk }}$ and $\mathrm{p} 42^{\text {mapk }}$ undergo rapid tyrosine and threonine phosphorylations in response to growth factors, as well as angiotensin II and endothelin-1, leading to stimulation of their intrinsic ki- nase activities (for reviews see references 42 and 43). Since thrombin-stimulated cells contained $42 / 44-\mathrm{kD}$ tyrosine phosphorylated proteins, we sought to determine if these proteins corresponded to the MAP kinases. Thrombin- and SFLLRNPstimulated RASM cell lysates were first immunoprecipitated with anti-p42/44 MAP kinase antibodies, and the immune complexes were resolved on SDS gels and immunoblotted with anti-P-TYR (Fig. $7 A$ ). In these experiments, anti-MAP kinase antiserum recovered two tyrosine phosphorylated bands of 42 and $44 \mathrm{kD}$. Unstimulated cells had no detectable levels of tyrosine phosphorylation of these proteins, corresponding to $\mathrm{p} 42^{\text {mapk }}$ and $\mathrm{p} 44^{\text {mapk }}$, respectively. These results imply that thrombin receptor activation leads to rapid tyrosine phosphorylation of MAP kinases, similar to many polypeptide growth factors and peptide agonists, including angiotensin II and endothelin-1.

Kinetics of thrombin-stimulated MAP kinase activation in comparison with that induced by $P D G F-B B$. A time course of MAP kinase activation in RASM cells was performed to determine whether the delayed mitogenic responses associated with $\alpha$-thrombin correlated with delayed activation of MAP kinase. Quiescent cultures of RASM cells were stimulated with either $\alpha$-thrombin or PDGF-BB, and MAP kinase activity was determined by quantitation of relative level MBP phosphorylation in $4^{\text {mapk }}$ immunoprecipitates. As shown in Fig. $8 \mathrm{~B}$, the $\mathrm{p} 44^{\text {mapk }}$ activation profile in response to either $\alpha$-thrombin or PDGF-BB exhibited similar kinetics, with the peak MAP kinase activity ( $\sim 20$-fold above control) occurring at $5 \mathrm{~min}$. Thrombin consistently stimulated MAP kinase activity to a greater extent than PDGF-BB, at least at the early time points (1-30 $\mathrm{min})$. We also observed that MAP kinase activity stimulated by either agonist was sustained for up to $6 \mathrm{~h}$, with no significant differences between the two agonists at later times.

It should be noted that although thrombin elicited weaker and delayed mitogenic responses in comparison to PDGF-BB

A
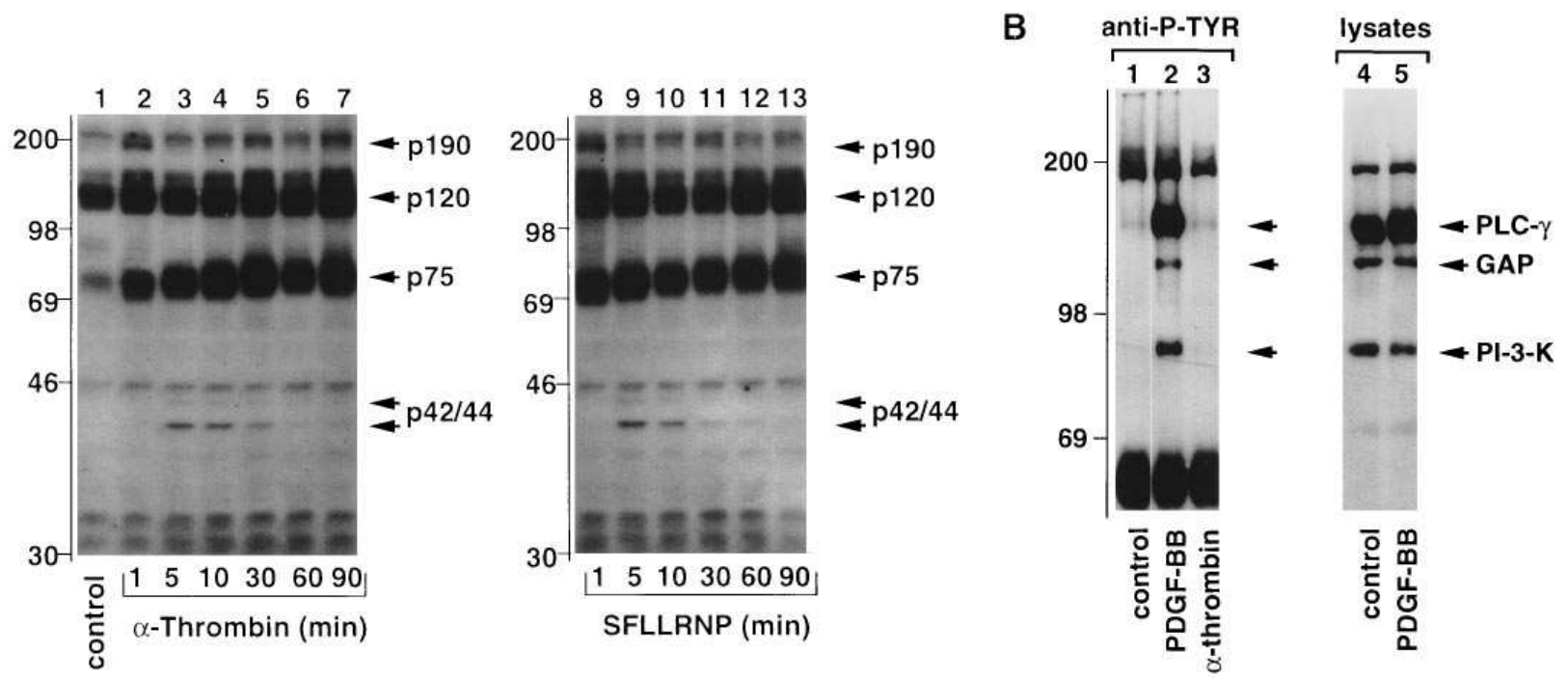

Figure 6. $\alpha$-Thrombin and SFLLRNP induce rapid protein tyrosine phosphorylation in RASM cells. (A) Anti-P-TYR immunoblot analysis of whole cell lysates from unstimulated RASM cells (lane 1) and cells stimulated by either $\alpha$-thrombin (10 nM, lanes 2-7) or SFLLRNP(100 $\mu$ M, lanes 8-10) for the indicated times. Arrows denote tyrosine phosphorylated proteins at 190 (p190), 120 (p120), 75 (p75), and 42/44 kD (p42/44). $(B)$ Serum-starved RASM cells were left untreated or were stimulated with either thrombin $(10 \mathrm{nM})$ or PDGF-BB (50 ng/ml) for $10 \mathrm{~min}$ as indicated. (Lanes 1-3) Anti-P-TYR recovered proteins, resolved on SDS gels (8\% acrylamide), were subjected to immunoblotting using a combination of antibodies directed against GAP, PI-3-K, and PLC- $\gamma$. (Lanes 4 and 5) Immunoblot of whole cell lysates using same combination of antibodies. Note that thrombin did not stimulate anti-P-TYR recovery of the PDGF-receptor substrates (compare lanes 2 and 3). Data are representative of independent experiments that were performed at least three times. 
A

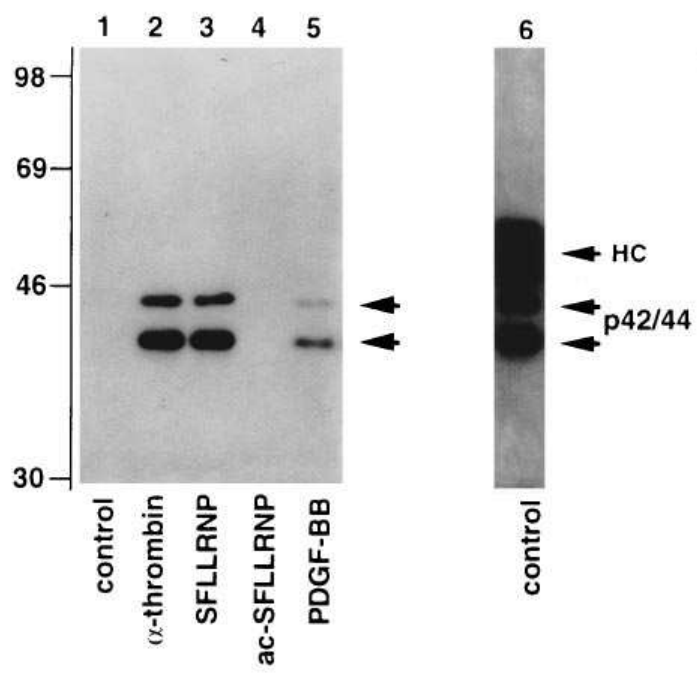

B

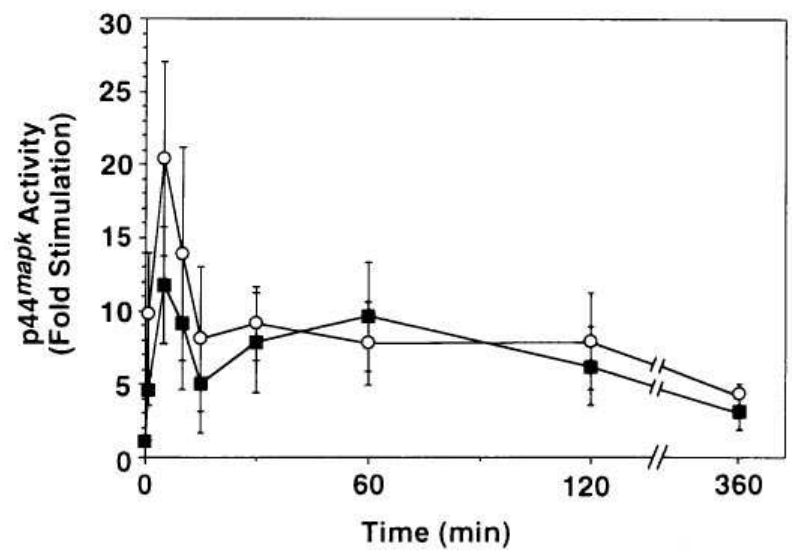

Figure 7. Thrombin receptor stimulation leads to tyrosine phosphorylation and activation of MAP kinases. ( $A$ ) Serum-starved RASM cells were left untreated (control) or were stimulated with thrombin $(10 \mathrm{nM})$, SFLLRNP $(100 \mu \mathrm{M})$, acetylated SFLLRNP $(100 \mu \mathrm{M})$, or PDGF-BB (50 ng/ml) for $5 \mathrm{~min}$ as indicated. (Lanes 1-5) Anti-PTYR immunoblot of proteins immunoprecipitated with anti-MAP kinase antibodies. (Lane 6) Anti-MAP kinase immunoblot of antiMAP-kinase recovered proteins from serum-starved RASM cells. Arrows denote two forms of MAP kinases in RASM cells, $\mathrm{p} 42^{\text {mapk }}$ and $\mathrm{p} 44^{\text {mapk }}$. HC indicates the immunoglobulin heavy chain of the anti-MAPk antibody that also binds $\left[{ }^{125} \mathrm{I}\right]$-protein A. (B) Confluent cultures of quiescent RASM cells were stimulated with either $\alpha$-thrombin (10 $\mathrm{nM}$, open circles) or PDGF-BB (50 ng/ml, closed squares) for the indicated times. Immunoprecipitates containing p44 ${ }^{\text {mapk }}$ were measured for their ability to stimulate incorporation of $\left[{ }^{32} \mathrm{P}\right]$ into MBP as described in Methods. Results are expressed as fold stimulation over serum-starved control cells and represent the mean $\pm \mathrm{SD}$ of three independent experiments.

in the RASM cells, it was found to activate $\mathrm{p} 44^{\text {mapk }}$ to a greater extent. Furthermore, since the kinetics of activation for $\mathrm{p} 44^{\text {mapk }}$ were comparable between PDGF-BB and thrombin, these results imply that the MAP kinase pathway alone is not sufficient to induce mitogenesis in these cells.

$\alpha$-Thrombin and SFLLRNP induce rapid activation of the cellular protein kinase, Raf-1. Activation of Raf- 1 is accompanied by multiple phosphorylations of the molecule on serine and threonine residues, which results in a characteristic retardation of the protein as it is resolved in SDS polyacrylamide gels ("gel shift," for reviews see references 44 and 45). Experiments were performed to evaluate the effects of thrombin and SFLLRNP on the activation of Raf-1 (Fig. 8). Quiescent RASM cells were stimulated with $\alpha$-thrombin or SFLLRNP for various times, and cell lysates containing equal protein were subjected to immunoblot analysis using an anti-Raf-1 peptide antiserum. Raf-1 was observed as a protein band which migrated with an apparent molecular mass of $70 \mathrm{kD}$ in unstimulated cells. Both $\alpha$-thrombin and SFLLRNP stimulation led to a rapid decrease in mobility of Raf- 1 , which was detected within $5 \mathrm{~min}$ of agonist addition. Under these conditions, the positively identified Raf- 1 protein migrated at a molecular mass of $\sim 74 \mathrm{kD}$. Gel-retarded Raf- 1 persisted for $>2 \mathrm{~h}$ after thrombin/SFLLRNP stimulation, indicating that activation of the thrombin receptor causes rapid and sustained activation of Raf- 1 in RASM cells. Consequently, this mechanism is likely involved in the rapid activation of MAP kinases stimulated by thrombin in these cells.

\section{Discussion}

This study demonstrates that activation of thrombin receptors in a well defined RASM cell line results in potent stimulation of DNA synthesis and cell proliferation. These findings support the concept that thrombin, aside from its well known effects in blood coagulation, may also directly regulate vascular smooth muscle cell proliferation in the vessel wall and potentially contribute to such processes as neointimal formation in restenosis and atherosclerosis. These data are consistent with recent studies reporting that $\alpha$-thrombin stimulates smooth muscle cell growth in culture $(5,6,9,18,23)$. Furthermore, they support in vivo studies that implicate thrombin in smooth muscle cell proliferation and neointimal formation after arterial injury (2-4).

An interesting observation in these studies was that thrombin-stimulated DNA synthesis was delayed in comparison to potent polypeptide growth factors or serum. These data are in agreement with previous studies using both rat (9) and human arterial smooth muscle cell lines $(34,46)$. Furthermore, the delayed mitogenic responses of RASM cells after thrombin receptor activation are similar to our previous studies on angiotensin II and endothelin-1, two other potent vasoactive agonists that bind to distinct $G$ protein-coupled receptors $(36,38)$. Taken together, these data support the hypothesis that various peptidic, G protein-coupled receptor agonists each stimulate RASM cell growth by a similar indirect mechanism (Fig. 9). In this model, delayed mitogenesis after stimulation of thrombin, angiotensin II (i.e., $\left.\mathrm{AT}_{1}\right)$, or endothelin-1 $\left(\mathrm{ET}_{\mathrm{A}}\right)$ receptors is preceded by the increased expression of a common subset of new gene products in RASM cells. These genes may code for known as well as "novel" growth factors that then act as the "proximal" autocrine mitogens that are ultimately responsible for cell growth.

Confirmation of this model has important therapeutic implications in vascular pathology. For example, specific vasoactive antagonists (e.g., $\mathrm{ACE}$ inhibitors, $\mathrm{AT}_{1}, \mathrm{ET}_{\mathrm{A}}$ receptor antagonists) would be predicted to be partially or completely ineffective in vascular proliferative disorders if sufficient amounts of a complimentary agonist (e.g., thrombin) predominate in affected vessels. In addition, individual vasoactive an- 
Figure 8. Thrombin receptor activation leads to hyper-

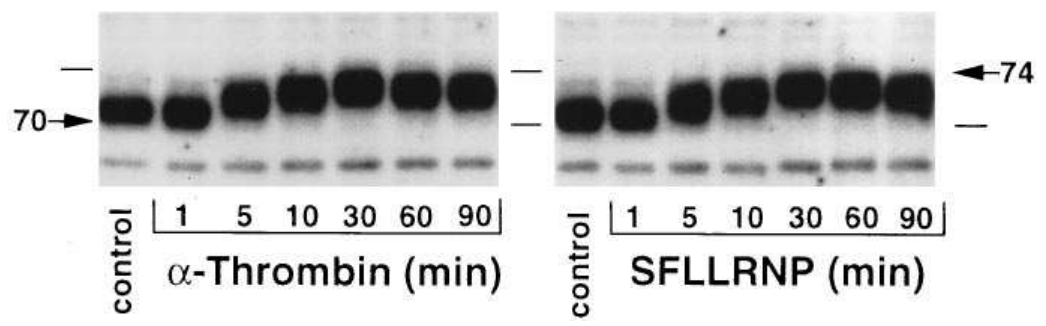
phosphorylation of Raf-1. Serum-starved RASM cells were left untreated (lanes 1 and 8 ) or were stimulated with thrombin (10 $\mathrm{nM}$, lanes $2-7)$ or SFLLRNP (100 $\mu \mathrm{M}$, lanes 9-14) for the indicated times. Immunoblots of total cell lysates equal to $100 \mu \mathrm{g}$ protein/lane were probed with rabbit anti-Raf-1 antiserum. Note that both thrombin and SFLLRNP addition to the cells caused a decreased mobility (gel-shift) of the major Raf-1 band from $70 \mathrm{kD}$ (unstimulated) to $\sim 74 \mathrm{kD}$, due to hyperphosphorylation of this protein (see text).

tagonists should be additive in their ability to attenuate neointimal formation by reducing the net expression of common autocrine mediators (Fig. 9). Thus, this model may partly explain the failure of some agents to attenuate post-PTCA restenosis (for reviews see references 47-49). Furthermore, it suggests a key role for thrombin in hyperproliferative vascular processes, which is supported by several studies describing a high incidence of thrombosis and concomitant overexpression of thrombin receptors in arterial lesions $(3,50-52)$.

Additional support for an autocrine mechanism for thrombin-stimulated proliferation has been derived from studies demonstrating increased expression of PDGF-A chain, bFGF, or heparin-binding epidermal growth factor-like growth factor in cultured vascular smooth muscle cells in response to thrombin $(33,35,53,54)$. Thus, these growth factors represent candidate proximal mitogens associated with thrombin-stimulated DNA synthesis. However, in these studies we have excluded PDGF and bFGF as significant external autocrine mitogens induced by thrombin in RASM cells. Furthermore, in preliminary experiments we have failed to identify a significant mito- genic contribution of heparin-binding epidermal growth factor-like growth factor in conditioned media samples obtained from thrombin-stimulated RASM cells. ${ }^{2}$ Thus, while it is possible that some of these factors may contribute to cell growth via an intracellular autocrine mechanism, additional studies will be required to identify the specific mitogens, intracellular and/or secreted, that are responsible for thrombininduced smooth muscle cell proliferation.

Thrombin receptor activation was also associated with stimulation of protein tyrosine phosphorylation in the RASM cells. Although the activation of this mechanism was rapid, some of the specific tyrosine phosphorylated proteins stimulated by thrombin or SFLLRNP were distinct from those induced by potent vascular smooth muscle mitogens such as PDGF. Thus, thrombin treatment did not stimulate tyrosine phosphorylation of PLC- $\gamma$, p2 $1^{\text {ras }}$ GAP, or PI-3-kinase, three direct substrates of receptor tyrosine kinases implicated in mitogenic signal transduction (39-41). In contrast, thrombin receptor activation resulted in tyrosine phosphorylation of two proteins of 75 and $125 \mathrm{kD}$ which we have identified as paxillin

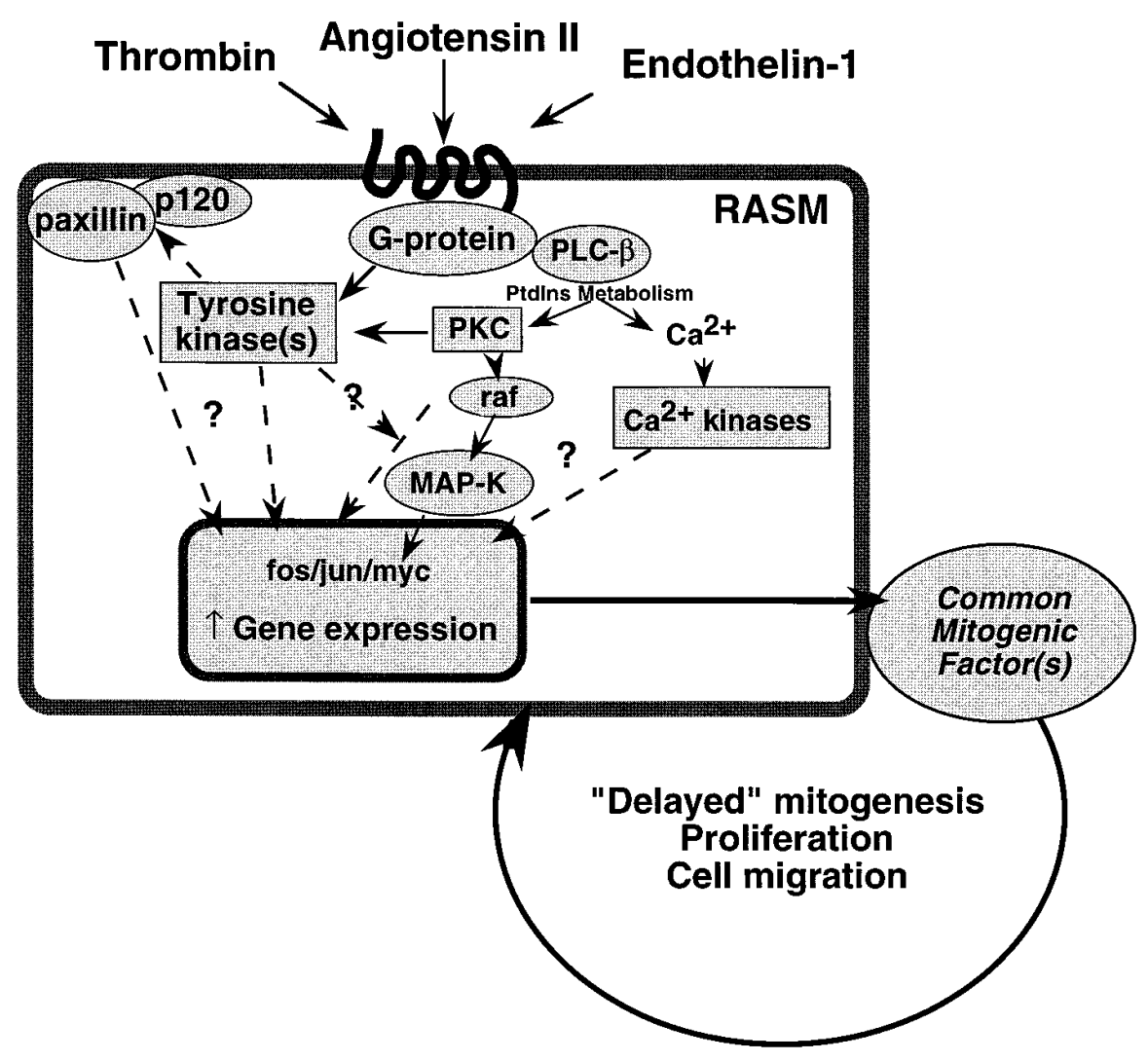

Figure 9. Autocrine model of delayed mitogenesis stimulated by $\mathrm{G}$ protein-coupled receptor agonists in cultured RASM cells. Binding of ligands to the appropriate receptor results in rapid intracellular signal transduction, including $\mathrm{G}$ protein-stimulated phosphatidylinositol (PtdIns) metabolism via phospholipase $\mathrm{C}-\beta_{1}(P L C-\beta)$, protein kinase $\mathrm{C}(P K C)$ activation, intracellular calcium $\left(\mathrm{Ca}^{2+}\right)$ mobilization, and calciumdependent protein kinase $\left(\mathrm{Ca}^{2+}\right.$ kinases $)$ activation. Intracellular protein tyrosine kinase(s) are also activated, leading to tyrosine phosphorylation of focal adhesion proteins, including paxillin. Downstream components in the early signaling cascade include Raf- 1 and MAP kinases. These early signaling events are hypothesized to lead to nuclear protooncogene transcriptional activation (c-fos, c-jun, c-myc) and increased expression of endogenous mitogenic factors. The secretion of one or more mitogenic factors results in the formation of a productive autocrine loop, resulting in cellular proliferation and/or migration (see text). 
and pp125 $5^{\mathrm{FAK}}$, respectively (Molloy, C.J., and C.E. Turner, unpublished observations; and references 55 and 56). Since tyrosine phosphorylation of these molecules was very rapid, they represent possible direct targets for the protein tyrosine kinase(s) associated with thrombin receptor activation. However, their exact role in thrombin-initiated signal transduction and cell proliferation remains to be determined.

The precise mechanisms responsible for functional coupling of activated thrombin receptors and protein tyrosine kinase activity are presently unknown. Thus, thrombin receptor activation may induce additional coupling to an intracellular protein tyrosine kinase or kinase cascade. However, the relevant tyrosine kinases involved in this process have yet to be identified. One candidate molecule is c-src. This nonreceptor tyrosine kinase is activated in mesangial cells in response to endothelin-1 (57) and appears to be transiently activated in CCL39 hamster lung fibroblasts in response to thrombin (58). A similar activation of c-src may occur in RASM cells, although in preliminary experiments we failed to observe any significant c-src activation after treatment of the cells with either thrombin or angiotensin II. ${ }^{2}$

A second candidate kinase is the focal adhesion kinase $\mathrm{pp} 125^{\mathrm{FAK}}$. Previous studies have demonstrated that phosphorylation of pp $125^{\mathrm{FAK}}$ frequently increases in parallel with paxillin tyrosine phosphorylation $(56,59)$. Furthermore, pp $125^{\mathrm{FAK}}$ becomes tyrosine phosphorylated in response to angiotensin II in RASM cells (55). Thus it is likely that this kinase is also activated by thrombin and may be involved in stimulation of paxillin phosphorylation.

Raf-1 and MAP kinases represent additional downstream signaling molecules in the thrombin receptor-initiated signal transduction cascade (Fig. 9). These data agree with similar results reported in astrocytoma cells (60) and platelets (61, 62 ). In this regard, thrombin receptor signaling shares some common features with other mitogenic factors, including growth factors and vasoconstrictors such as bFGF and PDGF, endothelin-1, and angiotensin II $(37,38,40,45)$. However, since the mitogenic effects of thrombin, angiotensin II, and endothelin-1 are delayed by several hours when compared with growth factors, these early biochemical signaling events apparently are not sufficient to induce DNA synthesis in RASM cells. These data are supported by various other studies. For example, Sakurai et al. (63) have shown that mitogenesis stimulated by activin A in Swiss 3T3 fibroblasts does not require activation of MAP kinases. Likewise, in our experiments we found that thrombin failed to stimulate significant levels of DNA synthesis in Swiss 3T3 cells, even though these cells contain thrombin receptors and elicit rapid intracellular $\mathrm{Ca}^{2+}$ mobilization, phosphoinositide metabolism, and MAP kinase activation in response to thrombin (Seiler, S.M., unpublished observations) (32).

These results imply that additional intracellular events are required for productive mitogenesis in RASM cells. These may include the delayed activation of molecules such as PLC- $\gamma$, GAP, p21 $1^{\text {ras }}$ and/or PI-3-kinase, implicated in mitogenic signaling initiated by certain growth factors, including PDGF, but not the G protein-coupled receptors (39-41). Furthermore, according to the autocrine RASM cell proliferation model (Fig. 9), the critical signaling events required for DNA synthesis in vascular smooth muscle cells should be affected specifically by endogenously produced mitogens elicited after thrombin receptor activation. Thus, comparisons between the early biochemical signaling pathways stimulated by both proximal and delayed (autocrine) mitogens in RASM cells may lead to identification of the precise biochemical mechanisms controlling DNA synthesis and cell cycle progression in this model system.

\section{Acknowledgments}

The authors would like to thank Dr. Tom Meek and Dr. William Koster for helpful discussions and critical reading of the manuscript.

This study was supported in part by grants from the Muscular Dystrophy Association and National Institutes of Health (GM 47607) awarded to Christopher E. Turner. C.E. Turner is an established investigator of the American Heart Association.

\section{References}

1. Glusa, E. 1992. Vascular effects of thrombin. Semin. Thromb. Hemostasis. 18:296-304.

2. Sarembock, I.J., S.D. Gertz, L.W. Gimple, R.M. Owen, E.R. Powers, and W.C. Roberts. 1991. Effectiveness of recombinant desulphatohirudin in reducing restenosis after balloon angioplasty of atherosclerotic femoral arteries in rabbits. Circulation. 84:232-243.

3. Walters, T.K., D.A. Gorog, and R.F.M. Wood. 1994. Thrombin generation following arterial injury is a critical initiating event in the pathogenesis of the proliferative stages of the atherosclerotic process. J. Vasc. Res. 31:173-177.

4. Wilcox, J.N., J. Rodriguez, R. Subramanian, J. Ollerenshaw, C. Zhong, D.J. Hayzer, C. Horaist, S.R. Hanson, A. Lumsden, T.A. Salam, et al. 1994. Characterization of thrombin receptor expression during vascular lesion formation. Circ. Res. 75:1029-1038.

5. Berk, B.C., M.B. Taubman, K.K. Griendling, E.J.J. Cragoe, J.W. Fenton, II, and T.A. Brock. 1991. Thrombin-stimulated events in cultured vascular smooth-muscle cells. Biochem. J. 274:799-805.

6. Huang, C.-L., and H.E. Ives. 1987. Growth inhibition by protein kinase C late in mitogenesis. Nature (Lond.). 329:849-850.

7. Vouret-Craviari, V., E. Van Obberghen-Schilling, U.B. Rasmussen, A. Pavirani, J.-P. Lecocq, and J. Pouysségur. 1992. Synthetic $\alpha$-thrombin receptor peptides activate $\mathrm{G}$ protein-coupled signaling pathways but are unable to induce mitogenesis. Mol. Cell. Biol. 3:95-102.

8. Carney, D.H., D.L. Scott, E.A. Gordon, and E.F. LaBelle. 1985. Phosphoinositides in mitogenesis: neomycin inhibits thrombin-stimulated phosphoinositide turnover and initiation of cell proliferation. Cell. 42:479-488.

9. McNamara, C.A., I.J. Sarembock, L.W. Gimple, J.W. Fenton II, S.R. Coughlin, and G.K. Owens. 1993. Thrombin stimulates proliferation of cultured rat aortic smooth muscle cells by a proteolytically activated receptor. J. Clin. Invest. 91:94-98.

10. Vu, T.-K.H., D.T. Hung, V.I. Wheaton, and S.R.C. Coughlin. 1991. Molecular cloning of a functional thrombin receptor reveals a novel proteolytic mechanism of receptor activation. Cell. 64:1057-1068.

11. Coughlin, S.R. 1994. Thrombin receptor function and cardiovascular disease. Trends Cardiovasc. Med. 4:77-83.

12. Ngaiza, J.R., and E.A. Jaffe. 1991. A 14 amino acid peptide derived from the amino terminus of the cleaved thrombin receptor elevates intracellular calcium and stimulates prostacyclin production in human endothelial cells. Biochem. Biophys. Res. Commun. 179:1656-1661.

13. Hung, D.T., T.-K.H. Vu, V.I. Wheaton, K. Ishii, and S.R. Coughlin. 1992. Cloned platelet thrombin receptor is necessary for thrombin-induced platelet activation. J. Clin. Invest. 89:1350-1353.

14. Rasmussen, U.B., V. Vouret-Craviari, S. Jallat, Y. Schlesinger, G. Pagés, A. Pavirani, J.-P. Lecocq, J. Pouysségur, and E. Van Obberghen-Schilling. 1991. cDNA cloning and expression of a hamster $\alpha$-thrombin receptor coupled to $\mathrm{Ca}^{2+}$ mobilization. FEBS Lett. 288:123-128.

15. Zhong, C., D.J. Hayzer, M.A. Corson, and M.S. Runge. 1992. Molecular cloning of the rat vascular smooth muscle thrombin receptor: evidence for in vivo regulation by basic fibroblast growth factor. J. Biol. Chem. 267:1697516979.

16. Liu, L.-W., T.-K.H. Vu, C.T. Esmon, and S.R. Coughlin. 1991. The region of the thrombin receptor resembling hirudin binds to thrombin and alters enzyme specificity. J. Biol. Chem. 266:16977-16980.

17. Van Obberghen-Schilling, E., and J. Pouysségur. 1993. Signalling pathways of the thrombin receptor. Thromb. Haemostasis. 70:163-167.

18. Berk, B.C., M.B. Taubman, E.J.J. Cragoe, J.W. Fenton II, and K.K Griendling. 1990. Thrombin signal transduction mechanisms in rat vascular smooth muscle cells. Calcium and protein kinase C-dependent and independent pathways. J. Biol. Chem. 265:17344-17350.

19. Chambard, J.C., S. Paris, G. L’Allemain, and J. Pouysségur. 1987. Two 
growth factor signalling pathways in fibroblasts distinguished by pertussis toxin. Nature (Lond.). 326:800-803.

20. Webb, M.L., D.S. Taylor, and C.J. Molloy. 1993. Effects of thrombin receptor activating peptide on phosphoinositide hydrolysis and protein kinase $\mathrm{C}$ activation in cultured rat aortic smooth muscle cells: evidence for "tetheredligand" activation of smooth muscle cell thrombin receptors. Biochem. Pharmacol. 45:1577-1582.

21. Ferrell, J.E., and G.S. Martin. 1988. Platelet tyrosine-specific protein phosphorylation is regulated by thrombin. Mol. Cell. Biol. 8:3603-3610.

22. Golden, A., and J.S. Brugge. 1989. Thrombin treatment induces rapid changes in tyrosine phosphorylation in platelets. Proc. Natl. Acad. Sci. USA. 86: 901-905.

23. Weiss, R.H., and R. Nuccitelli. 1992. Inhibition of tyrosine phosphorylation prevents thrombin-induced mitogenesis, but not intracellular free calcium release, in vascular smooth muscle cells. J. Biol. Chem. 267:5608-5613.

24. Giachelli, C., N. Bae, D. Lombardi, M. Majesky, and S. Schwartz. 1991. Molecular cloning and characterization of $2 \mathrm{~B} 7$, a rat mRNA which distinguishes smooth muscle cell phenotypes in vitro and is identical to osteopontin (secreted phosphoprotein I, 2aR). Biochem. Biophys. Res. Commun. 177:867873 .

25. Vogel, U.S., R.A.F. Dixon, M.D. Schaber, R.E. Diehl, M.S. Marshall, E.M. Scolnick, I.S. Sigal, and J.B. Gibbs. 1988. Cloning of bovine GAP and its interaction with oncogenic ras p21. Nature (Lond.). 335:90-93.

26. Seiler, S.M., H.J. Goldenberg, I.M. Michel, J.T. Hunt, and G.B. Zavoico. 1991. Multiple pathways of thrombin-induced platelet activation differentiated by peptide desensitization and by thrombin exosite inhibitors. Biochem. Biophys. Res. Commun. 181:636-643.

27. Di Marco, E., J.H. Pierce, T.P. Fleming, M.H. Kraus, C.J. Molloy, S.A. Aaronson, and P.P. Di Fiore. 1989. Autocrine interaction between TGF $\alpha$ and EGF-receptor: quantitative requirements for induction of the malignant phenotype. Oncogene. 4:831-838.

28. Molloy, C.J., D. Bottaro, T.P. Fleming, M.S. Marshall, J.B. Gibbs, and S.A. Aaronson. 1989. PDGF induction of tyrosine phosphorylation of GTPase activating protein. Nature (Lond.). 342:711-714.

29. Pages, G., P. Lenormand, G. L'Allemain, J.-C. Chambard, S. Meloche, and J. Pouysségur. 1993. Mitogen-activated protein kinases $\mathrm{p} 42^{\text {mapk }}$ and $\mathrm{p} 44^{\text {mapk }}$ are required for fibroblast proliferation. Proc. Natl. Acad. Sci. USA. 90:83198323.

30. Clemmons, D.R., and J.J. Van Wyk. 1985. Evidence for a functional role of endogenously produced somatomedin-like peptides in the regulation of DNA synthesis in cultured human fibroblasts and porcine smooth muscle cells. J. Clin. Invest. 75:1914-1918.

31. Stiles, C.D., G.T. Capone, C.D. Scher, H.N. Antoniades, J.J. Van Wyk, and W.J. Pledger. 1979. Dual control of cell growth by somatomedins and platelet-derived growth factor. Proc. Natl. Acad. Sci. USA. 76:1279-1283.

32. Gardner, A.M., R.R. Vaillancourt, and G.L. Johnson. 1993. Activation of mitogen-activated protein kinase/extracellular signal-regulated protein kinase kinase by $\mathrm{G}$ protein and tyrosine kinase oncoproteins. J. Biol. Chem. 268: 17896-17901.

33. Weiss, R.H., and M. Maduri. 1993. The mitogenic effect of thrombin in vascular smooth muscle cells is largely due to basic fibroblast growth factor. $J$. Biol. Chem. 268:5724-5727.

34. Kanthou, C., G. Parry, E. Wijelath, V.V. Kakkar, and C. DemoliouMason. 1992. Thrombin-induced proliferation and expression of plateletderived growth factor-A chain gene in human vascular smooth muscle cells. FEBS Lett. 314:143-148.

35. Stouffer, G.A., I.J. Sarembock, C.A. McNamara, L.W. Gimple, and G.K. Owens. 1993. Thrombin-induced mitogenesis of vascular SMC is partially mediated by autocrine production of PDGF-AA. Am. J. Physiol. 265:C806C811.

36. Weber, H., D.S. Taylor, and C.J. Molloy. 1994. Angiotensin II induces delayed mitogenesis and cellular proliferation in rat aortic smooth muscle cells. Correlation with the expression of specific endogenous growth factors and reversal by suramin. J. Clin. Invest. 93:788-798.

37. Molloy, C.J., D.S. Taylor, and H. Weber. 1993. Angiotensin II stimulation of rapid protein tyrosine phosphorylation and protein kinase activation in rat aortic smooth muscle cells. J. Biol. Chem. 268:7338-7345.

38. Weber, H., M. Webb, R. Serafino, D.S. Taylor, S. Moreland, J. Norman, and C.J. Molloy. 1994. Endothelin-1 and angiotensin II stimulate delayed mitogenesis in cultured rat aortic smooth muscle cells: evidence for common signaling mechanisms. Mol. Endocrinol. 8:148-158.

39. Aaronson, S.A. 1991. Growth factors and cancer. Science (Wash. DC). 254:1146-1153.
40. Cantley, L.C., K.R. Auger, C. Carpenter, B. Duckworth, A. Graziani, R. Kapeller, and S. Soltoff. 1991. Oncogenes and signal transduction. Cell. 64:281-302.

41. Fantl, W.J., D.E. Johnson, and L.T. Williams. 1993. Signalling by receptor tyrosine kinases. Annu. Rev. Biochem. 62:453-481.

42. Blenis, J. 1991. Growth regulated signal transduction by MAP kinases and RSKs. Cancer Cells (Cold Spring Harbor). 3:445-449.

43. Boulton, T.G., S.H. Nye, D.J. Robbins, N.Y. Ip, E. Radziejewska, S.D. Morgenbesser, R.A. DePinho, N. Panayotatos, M.H. Cobb, and G.D. Yancopoulos. 1991. ERKs: a family of protein-serine/threonine kinases that are activated and tyrosine phosphorylated in response to insulin and NGF. Cell. 65: $663-675$.

44. Crews, C.M., and R.L. Erikson. 1993. Extracellular signals and reversible protein phosphorylation: What to mek of it all. Cell. 74:215-217.

45. Li, P., K. Wood, H. Mamon, W. Haser, and T. Roberts. 1991. Raf-1: a kinase currently without a cause but not lacking in effects. Cell. 64:479-482.

46. Hedin, U., S. Frebelius, J. Sanchez, M. Dryjski, and J. Swedenborg. 1994. Antithrombin III inhibits thrombin-induced proliferation in human arterial smooth muscle cells. Arterioscler. Thromb. 14:254-260.

47. O'Brien, E.R., and S.M. Schwartz. 1994. Update on the biology and clinical study of restenosis. Trends Cardiovasc. Med. 4:169-178.

48. Jackson, C.L. 1994. Animal models of restenosis. Trends Cardiovasc. Med. 4:122-130.

49. Schwartz, R.S. 1994. Neointima and arterial injury: dogs, rats, pigs, and more. Lab. Invest. 71:789-791.

50. Wilcox, J., J. Ollerenshaw, C. Zhong, D.J. Hayzer, J. Rodriguez, R.R. Subramanian, L.A. Harker, S.R. Hanson, A.B. Kelly, and M.S. Runge. 1992. Localization of thrombin receptor expression in proliferating smooth muscle cells in vivo. Circulation. 86:I-250.

51. Marmur, J.D., M.B. Taubman, and V. Fuster. 1993. Pathophysiology of restenosis: the role of platelets and thrombin. J. Vasc. Med. Biol. 4:55-63.

52. Nelken, N.A., S.J. Soifer, J. O'Keefe, T.-K.H. Vu, I.F. Charo, and S.R Coughlin. 1992. Thrombin receptor expression in normal and atherosclerotic human arteries. J. Clin. Invest. 90:1614-1621.

53. Okazaki, H., M.W. Majesky, L.A. Harker, and S.M. Schwartz. 1992. Platelet-derived growth factor ligand and receptor gene expression is regulated by alpha-thrombin in vascular smooth muscle cells. Circ. Res. 71:1285-1293.

54. Nakano, T., E.W. Raines, J.A. Abraham, F.G. Wenzel, IV, S. Higash iyama, M. Klagsburn, and R. Ross. 1993. Glucocorticoid inhibits thrombin induced expression of platelet-derived growth factor A-chain and heparin-binding epidermal growth factor-like growth factor in human aortic smooth muscle cells. J. Biol. Chem. 268:22941-22947.

55. Turner, C.E., K.M. Pietras, D.S. Taylor, and C.J. Molloy. 1995. Angiotensin II stimulation of rapid paxillin tyrosine phosphorylation correlates with the formation of focal adhesions in rat aortic smooth muscle cells. J. Cell Sci. 108:333-342.

56. Turner, C.E. 1994. Paxillin: a cytoskeletal target for tyrosine kinases. BioEssays. 16:47-52.

57. Simonson, M.S., and W.H. Herman. 1993. Protein kinase C and protein tyrosine kinase activity contribute to mitogenic signaling by endothelin-1. $J$. Biol. Chem. 268:9347-9353.

58. Chen, Y.-H., J. Pouysségur, S.A. Courtneidge, and E. Van ObberghenSchilling. 1994. Activation of src family kinase activity by the $\mathrm{G}$ protein-coupled thrombin receptor in growth-responsive fibroblasts. J. Biol. Chem. 269:2737227377.

59. Burridge, K., C.E. Turner, and L.H. Romer. 1992. Tyrosine phosphorylation of paxillin and pp125FAK accompanies cell adhesion to extracellular matrix: a role in cytoskeletal assembly. J. Cell Biol. 119:893-903.

60. LaMorte, V.J., E.D. Kennedy, L.R. Collins, D. Goldstein, A.T. Harootunian, J.H. Brown, and J.R. Feramisco. 1993. A requirement for Ras protein function in thrombin-stimulated mitogenesis in astrocytoma cells. J. Biol. Chem. 268:19411-19415.

61. Nakashima, S., Y. Chatani, M. Nakamura, N. Miyoshi, M. Kohno, and Y. Nozawa. 1994. Tyrosine phosphorylation and activation of mitogen-activated protein kinases by thrombin in human platelets: possible involvement in late arachidonic acid release. Biochem. Biophys. Res. Commun. 198:497-503.

62. Papkoff, J., R.-H. Chen, J. Blenis, and J. Forsman. 1994. p42 mitogenactivated protein kinase and p90 ribosomal S6 kinase are selectively phosphorylated and activated during thrombin-induced activation and aggregation. $\mathrm{Mol}$. Cell. Biol. 14:463-472.

63. Sakurai, T., Y. Abe, Y. Kasuya, N. Takuwa, R. Shiba, T. Yamashita, T. Endo, and K. Goto. 1994. Activin A stimulates mitogenesis in Swiss 3T3 fibroblasts without activation of mitogen-activated protein kinases. J. Biol. Chem. 269:14118-14122. 